Film Take

\title{
Spielberg's Deus ex Machina
}

\section{Saving Private Ryan}

Kenneth De Luca

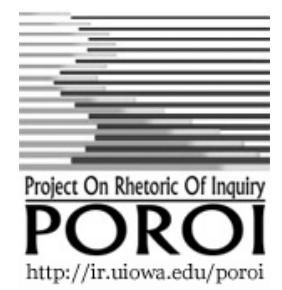

Poroi, 4, 2, J uly, 2005

1 Democracy premises that every citizen counts, and should count the same. So nothing stresses democracy more than war. Its effects are about as unequal as they come. Through war, some people become rich, famous, or powerful; some are untouched; some lose everything. During war, there is a gap, perhaps a chasm, between the principles and the realities of democracy. Into the breach marches the theorist. Is this gap proof of hypocrisy? Can the gap be explained away? Is the regime worth fighting for? What theorist could resist such questions?

2 One who could not is the Pericles in Thucydides' History of the Peloponnesian War. There the funeral oration of Pericles is, in part, an attempt to overcome a democratic gap between principles and realities. The gap is manifest the moment Pericles opens his mouth, and he knows it, as suggested by the fact that his speech begins by criticizing the Athenian lawgiver for requiring a speech. Deed should be repaid by deed, Pericles asserts, not speech. Mandating a speech is unwise, Pericles reasons, because a speech singles out individuals, those who died, and the man who makes the speech. This works against Pericles' desire to unite the city. So his funeral oration scarcely mentions death, which is always someone's death, and does not address the heroic acts of particular individuals.

3 Though Pericles begins by blaming the lawgiver, the fault falls to the complexity of democracy. On the one hand, democracy arouses public spiritedness because the people rule. In a sense, the regime belongs to them. Therefore the public realm - that is, the public good, the laws, the Assembly where the laws are made, civic virtue, justice - is sacrosanct. On the other hand, the principle of democracy is equality. In a democracy, no one should tell others how to live. In a democracy, accordingly, people feel they have the right to their own things. This also makes the private realm - the family, home life, bodily pleasures, leisurely 
pursuits - sacrosanct. Beneath the surface, democracy can conflict with itself: private pitted against public, public against private. The funeral oration attempts to overcome the conflict by projecting a beautiful image of the city. Whether Pericles succeeds is doubtful: immediately following his inspiring account of Athens, Thucydides provides an ugly, dispiriting story of Athens under the plague. Thucydides suggests that the plague refutes Pericles twice: it proves that democracy remains an unsolved problem, and it kills him.

4 The difficulties that democracies can have in squaring public and private persist to this day, and they continue to attract the theoretically minded. They configure Steven Spielberg's recent film about the Second World War, and the title implies their primacy: not "Saving Soldier Ryan" but Saving Private Ryan. The film focuses on tensions between public (winning the war) and private (saving the last surviving male member of a particular family); and like the Pericles oration, the Spielberg film treats public/ private as a defining challenge for democracy. In trying to bridge Athenian gaps between public and private, the funeral oration becomes Pericles' love poem to Athens. This essay explores how Saving Private Ryan becomes Spielberg's poetic response to an American version of this challenge.

\section{Saving Private Ryan: The Preface}

5 Right before the most famous scenes in Saving Private Ryan, the landing at Omaha Beach, the camera zooms in on the eyes of a focal character. The film has not identified him yet, but we know he is American. Watching his eyes stare into the distance, we hear - but do not see - the sound of waves. That we hear waves while peering into the man's eyes can suggest that we are being given access to his thoughts. The sound of waves and the waves of American troops about to occupy the screen provide matches in setting and concept to create a sense of internality. Thus the most famous scenes of Saving Private Ryan, the brutally realistic depictions of the military landing, are history at two removes. They are the director's portrayals of how a particular figure envisions what happened. A fictional man's private meditation is our means of entry to this most public day.

6 The day's public significance has earned it a name: "D-Day." By name, the day is now part of America's history and language. High casualties contributed to the day's importance. The private realm was never more subordinated to the public realm, for on 
this day thousands gave their most guarded possession, their own lives, for the sake of the public good - for national security and freedom.

7 This public day marked a, perhaps the, turning point in the war. D-Day greatly improved Allied prospects. The setting at the start of the film - the World War II Normandy American Cemetery and Memorial - confirms this, for days are rarely honored on this scale. To introduce this public day and the war that it turned, however, the film projects one man's private anguish. It suggests that we appreciate D-Day and the surrounding events through their importance to one man. Is Saving Private Ryan for the many or for the one? Does it animate love of country, or is it a clever privatization scheme? Let us return to the film's start with these questions in mind.

8 Saving Private Ryanbegins with the United States flag. It fills the screen. Blowing in the wind, the flag does not yield its position, yet it has no discernible connection to the ground. Suspended in air, the flag is bathed in light. If it were to drop from sight, we would be looking at the sun. The film puts the flag first; and in a way, it supplants the sun: the flag gives us reason to look up, the flag warms us; the flag sheds meaning on situation. The film accompanies this beautified image of the flag with sublime music on regal horns.

9 Since the flag symbolizes the United States of America, the film glorifies the country in glorifying the flag. This beginning announces that Saving Private Ryan is an unabashed exercise in patriotism. The film ends exactly this way, too, suggesting that what takes place between its first and last frames connects to the flag and to the ideals for which it stands. The flag may be out of sight at times in the film's middle, but it is never out of mind.

10 After its patriotic beginning, Saving Private Ryan shows a man walking. It attends to his shoes. The shift from the deified flag is abrupt, stark, but the patriotic music continues. What can be patriotic about an old man's shoes? Shoes seem to symbolize what is not patriotic, what is private and particular. For example, there is the saying, "never judge a man until you have walked a mile in his shoes." Shoes signify a person's particular experiences of the world. Their wear can reflect this, and trained eyes can tell much about a man from his shoes. The ability of Sherlock Holmes to study shoes and learn from their wear or the earth that sticks to them helps him penetrate the secrets of individuals. 
Shoes often need to be broken in: molded to suit the shape of specific feet, an individual gait, a personal manner of getting around. This man limps; that man sprints. Shoes individuate and point to how much we depend on the private realm for happiness. A saying of Socrates, probably apocryphal, is that, "when the feet hurt, we hurt all over."1 J ust as happiness might not derive from the feet but can be derailed by ill-fitting shoes, so it may depend on private life: not on country, not on patriotism. The road to happiness is for our feet. It does not fly on high, like the flag or vaporous ideals.

11 Yet the film asserts continuity between the first scene and the second. Why? The first soars with patriotism, while the next is literally on the ground. We might wonder whether Saving Private Ryan attempts to extol patriotism or define it out of existence. Is the film saying that America is a country worthy of esteem because it is dedicated to providing basic comforts? If this were the case, the film might imply that there is no public good, per se, only private goods. Then the United States could be celebrated as a great country and a true democracy because it offers comforts for everyone to enjoy. It would be great because it enables people to be happy individually and in private. Is this, according to the film, the American version of patriotism rightly understood?

12 The camera pulls back to show that a family follows the walking man. Its members are several yards behind him. As the flag stood in relation to us in the film's first frame, he now stands in relation to his family. The flag is all we saw; the man is all they see. They gaze on him in respect, even reverence. His son photographs his back as the old man advances down a path. The film's camera paid tribute to the flag; now the son's camera pays tribute to his father. This family loves this progenitor and glorifies their bond as the film first glorified the flag. Thus the film equates flag and family, public and private, although we do not know whether this reconciles them or reduces the public to the private.

13 Trees line the path, and the family walks in rows. In the back, furthest from the old man, are three girls young enough to be his grandchildren. In the middle, a few feet in front of the girls, are the son and possibly the son's wife, who holds the hand of a young boy. In the front is the old man's wife. The family follows in three rows for its three generations: past, present, and future. Walking ahead, separated from his family, the man stands 
outside this kind of time. For the moment, at least, he moves beyond family trees to become more individual. Even the man's family might be too public. He needs space; his family grants it. His wife looks mystified: perhaps not sure why they are here or why her husband moves ahead. The end of the film confirms this feeling when the wife makes clear that she has not known about Captain Miller, whose grave her husband has come to honor. The film's events explain the old man's pilgrimage, yet he has withheld them for decades. These early scenes glorify the family, but they show that part of its glory is its respect for the individual - the true seat of the private realm.

14 Reaching the end of the path, the old man pauses by a tree and surveys the next phase of his journey. He is not so much tired as troubled by the ground to come. Looking just ahead, we see, each on its own pole, the flag of the United States then the flag of France flying next to it. The flags mark a threshold he is about to cross. When he passes between them and onto a grass field, he walks more slowly, and his face brims with feeling. A few strides show us that he is in a vast field of burial monuments. The identical white crucifixes and the occasional Star of David distinguish the D-Day Memorial Cemetery. We see the myriad gravestones in a wide-angle shot that amplifies our sense of the man's grief.

15 If we didn't already, we now care about the man. In generating sympathy for him in this way, though, is the film being fair to those memorialized? Does his private anguish deserve a spot on the same field with all the people whose sacrifice helped beat back one of the greatest threats to freedom the world has known? And is the film in effect robbing the graves of heroes to sell tickets? We shall see.

16 The man walks on, and his emotion grows. The music becomes more sentimental, bonding us to him. His grief is ours. In a moment, his inner state might dominate the whole film. Why is it so important that we see the film through his tearful eyes?

17 Amid the sea of memorials, we understand its threshold. America and France still fly flags, America and France still live, but the field is full of men who died. America and France live, in part, because these men fought to the death. America and France still live, but these men live only in memory. Did they live long enough to generate families to remember them, as our man will be remembered by his family when he joins the dead? If some did 
father families, the war cut short their opportunities to bond with children, to give children something to hold dear and pass on.

Dead fathers can leave behind the example of their service, but this is abstract. It lacks the individuality of the strange photograph of the old man's back, available to be handed down to his posterity. The field preserves the individuality of its dead in name only. As far as we can see, the memorials do not even attempt to distinguish how each man fought and died.

18 The names announce human individuality, but the field's effect for us is to suppress it. In this democracy of death, all seem equal co-participants in the war. Does the beauty of crosses and stars row on row compensate the deceased for families forfeited? The scene asks how we could repay these men for their sacrifice. It has enabled the old man, his family, and us to enjoy the fruits of private life. But did these men surrender their lives for a little stone and flying cloth? Perhaps under the weight of such questions, the man stumbles to his knees in front of a stone, one in particular that we cannot read, as his distant eyes transport us to Omaha Beach.

\section{Freedom's Altar}

19 As Saving Private Ryan turns to the American landing at the Dog Green Sector of Omaha Beach, the first things we see are obstacles arranged in the shallows. These recall the crucifixes of the memorial: identical shapes arrayed methodically in lines. The Germans seem prepared for the American landing. The beach has been "pre-sighted," and the Americans are throwing themselves into a firing squad.

20 Cutting from the war memorial to the war, the film turns from crosses of commemoration to crosses of crucifixion. The landing scene is shot at eye level in close-up perspective. We do not hover above it, enabling us to abstract from casualties and to take comfort in progress being made. Nor do we see it from a remote horizontal vantage that would mute the suffering. Instead we see and hear almost everything from the perspective of a participant. It is as if we are there. Bullets whiz by us like darts of lightning. Bombs shake us. The film amplifies the carnage rather than suppressing it. Limbs fly, intestines spill, a face becomes a gaping whole.

21 In battle, the private yields to the public. Every injury, every death does this; and the film displays it graphically. It shows men 
turned inside out. Some pray, others cry for their mothers. Some vomit, others cannot keep their hands from trembling. The battle causes men to forfeit self-control. The modus operandi is Greek: pathei mathos. Learning requires suffering.

22 The World War II Memorial and Cemetery that introduces the film would institutionalize the memory of sacrifices for the public good. But it is too general; and like most institutions, it runs the risks of failing to reproduce the sentiments that inspired it or convey acutely why it was established. It does little to communicate what men did and suffered to warrant its creation. The memorial and the men buried there need supplements, and the battle scenes would provide them. The aim is to make what these men experienced into fresh memories. Words and stones are not enough; we need images of what the men endured, and the beach scenes serve us well.

23 Yet these scenes also begin to contrast America to Germany. After the obstacles, we see a fleet of Higgens landing crafts, a man's trembling hands, then a close-up of the man himself. Is this the man at the war memorial? Are his the eyes through which we see? The film guards its answer until the end. So important is the private realm to Saving Private Ryan that it, too, keeps a realm private. We do learn that the man is an officer, for he orders his unit to disembark the Higgens. Forced to stand shoulder to shoulder on the boat, the men are especially vulnerable. A sergeant tells them to keep distance between one another in disembarking, since "five men are a juicy opportunity, one man is a waste of ammo."

24 When the landing ramp goes into the water, bullets slam the men before they can take a step. Seeing that the ramp is unusable, the officer with the trembling hands orders his men over the sides. The film cuts to an elevated, fortified bunker where German machine guns mow down the officer's men. We see how exposed the Americans are. It is a wonder that so make it from the landing crafts to the water obstacles that they use for cover.

25 Our officer is among them, though he barely knows it. We rejoin him in the midst of a shell shock. The film simulates his disorientation for us while, for a strange moment, he takes our perspective as an observer. Helmet in hand, he watches numbly as some of his soldiers incinerate themselves with their own flame thrower. Then another picks up and marches off with his own arm. At the war memorial, the old man's vision gave us ours; in 
the battle for the beach, our perspective is the officer's. Why does the film grant him this position of authority over us?

26 The officer re-helmets himself, a soldier screams in his face, and the officer rejoins the action. Now we know his name and rank. Captain Miller orders his sergeant, Horvath, to get the men off the beach. A soldier asks Miller where to rally. "Anywhere but here!" he says, and the response is telling. The order and the response leave blank spaces that the soldiers must fill. To be effective, Miller's order needs their participation. In effect, Miller shares authority with them. As his men prepare to storm a radar site, later in the film, Miller asks, “Who's going left?" He is commanding citizens of a democracy, and its principles are apparent in his exercise of authority.

27 Proceeding a few paces, Miller spots the "sea wall" and orders his men to move toward it. They are reluctant to leave the minimal cover of the landing obstacles, and one soldier directly disobeys the command. Miller appeals tepidly to principle: the men must move on to "make way for the others." If his men stay where they are, they will impede the ones to come and make those easier for Germans to kill. Soldiers who refuse Miller's order will become co-killers of their comrades. Miller could have pulled rank, invoked their great cause, or chastised the soldier for insubordination and cowardice. Instead he shifts from democratic turn-taking or fellowship to self-preservation and personal example: "every inch of this beach has been presighted. . . . if you stay here you're dead men." Then Miller runs forward. An invocation of force would insult a citizen of democracy, and an appeal to patriotism could suggest in context that the country has scant regard for the soldier's life. When Miller heeds his own warning, though, his soldiers are persuaded.

28 On his way to the sea wall, Miller meets a soldier who is part of a medical unit trying to set-up an area to treat the wounded. On the spur of the moment, Miller recommissions the whole group. Sensing that the foe would give no quarter to the wounded, Miller tells them to grab weapons and follow him. Despite the demands of duty to care for the wounded, it would be futile to make a medical camp there. This is no time for robotic - unfree and undemocratic - devotion to duty.

29 Soon afterward, Miller intercepts another soldier whom he tries to recommission. This one is with the Navy, however, so Miller has no authority over him. The man's mission is to clear the 
beach for tanks to land. Miller reports that "all the armor is foundering in the channel." Because it cannot arrive anytime soon, clearing obstacles can wait. The man replies, "Orders, sir. You go somewhere else! I'm clearing this one!" With a wounded soldier in tow, Miller resumes his advance towards the sea wall and the shooting.

30 By this point, Miller has encountered a soldier for whom orders do not matter and a soldier for whom nothing matters but orders. The first withdraws into himself, disregarding the community and his obligations to it; the last withdraws into the law, disregarding changes in circumstances that may authorize the adjustments. The first is all particular and no universal; the last is all universal and no particular. Miller is between these extremes. Unlike the first soldier, Miller is devoted to his mission and accepts his place in the hierarchy of command. Unlike the second soldier, Miller refuses to rely mindlessly on orders or hierarchy. He resists sacrificing himself or his men to abstractions. He stays sensitive to particulars. In making the medical unit receptive to Miller's redirection, the film highlights his virtue, for the doctors must share it in navigating between universal examples in textbooks and idiosyncrasies of particular patients.

31 Miller's middle position helps explain his sympathy and innovation. Miller's sympathy is on display in his attempt to drag a wounded soldier to the sea wall. It surfaces in tracking his men killed in action and in his later treatment of the James Ryan of Minnesota. His innovation shows in ordering his men over the side of the Higgens, recommissioning the medical unit, planning later to take a radar site, and improvising a defense for a bridge. The film calls attention to Miller's dexterous mind at the bridge when it has Corporal Henderson ask him about a type of ordnance, "sticky bombs," that Miller has said will enable them to disable tanks. The corporal has never heard of "sticky bombs" and asks Miller, “Did you just make that up?" Whether Miller invented it on the spot is irrelevant; the point is he knows what to do on the spot.

32 Since Miller does not fall back on cold moral abstractions, he is never blind to the suffering of his comrades or to the demands of circumstance. Nor is he harsh. In his encounter with the Navy man, Miller dispassionately explains why the man should change course. The Navy man, by contrast, screams. He is all thumos, as men blindly devoted to principle often are. Miller might be the 
only character in the history of war movies never to display a thumotic moment during high-pitched battles. Not only does Miller not allow thumos to rule, he defuses it. When his men get angry at the sight of the Germans continuing to shoot a downed courier, Miller tells them, "we do the same thing." He explains that, as long as air fills his lungs, the courier is fair game. Although the film's title calls attention to Private Ryan, Miller is the film's most remarkable character. The film's central problem is not saving Ryan in itself but the effect that saving Ryan has on Miller as well as Ryan. The mission to save Ryan puts Miller's virtue to the test.

33 When Miller and several comrades eventually make their way to the sea wall and its moderate cover, he discovers that he is the ranking officer and that all the units have been mixed up. "No one is where they are supposed to be." In this chaos, Miller locates the planned "Dog One Exit" and engineers a successful assault on the German bunkers, making the planned exit a reality.

34 Miller's thinking under fire is quick, clever, courageous. When Germans shoot from behind a wall, Miller improvises an assessment. He pulls out a mirror, grabs gum from a soldier's mouth, and borrows a dagger. Using the gum as adhesive, he mounts the mirror on the dagger and sticks his contraption around the corner to learn the German position. When he orders a soldier into harm's way, Miller draws the fire of German gunners to himself to facilitate the man's safe passage. Moves like these happen in a heartbeat.

35 Miller's opposite is not the Navy man but the Nazi army. Whereas Miller responds to particulars, the Nazis hold relentlessly to abstractions that would impose themselves on events. The film symbolizes Miller's foes with machine guns to suggest their operation as technocratic machines. At least three times during the assault on the beach, chance occurrences dramatize the vulnerability of Miller and his men to these killing machines. Under heavy fire, Wade, the unit's doctor, works to stop bleeding from the chest of the battalion surgeon. The fire is so heavy that Miller orders Wade's team off the beach, but Wade will not leave his patient. J ust as his efforts seem to pay off, as he exultantly shouts that the bleeding has been stopped, a bullet pierces the patient's helmet, killing him. Disgusted, Wade throws his bandages to the ground and curses the Germans, saying, "Give us a fucking chance." At the sea wall, a soldier shouts in Miller's ear that "they're killing us! We don't have a fucking chance, and 
that ain't fair!" But also at the sea wall, a soldier's helmet deflects a bullet to save his life. In stunned disbelief, the soldier removes his helmet to feel his head and reassure himself that he is not about to die. A comrade who sees this calls him a "lucky bastard." A moment later, though, a bullet hits his now unprotected head and kills him. Technology works to conquer chance and by staying blind to particulars. It does not distinguish between the wounded and the unwounded. Miller and his men face a Nazi army depicted as soulless killing machines.

36 Miller is anything but machine-like. As a master of discretion, his most important part is his head. Twice the film puts us "inside" it during Miller's bouts of shell shock: on the beach at Normandy beach and later at the bridge. The implication may be that Miller is lost without his head, without his wits, whereas the Germans are too often nothing without their technology. In this scene they are depicted as mere extensions of it. Americans depend at times on technology and act mechanically, of course, and Germans can improvise; still the film pursues an overall contrast of emphasis between America and Nazi Germany. Its frequent views of the German side let us see only helmets and gun tips, never faces. For faces might remind us that, the individuals beneath the helmets and holding the guns have minds of their own, families, and private lives. The film reinforces this device when, at the bridge, Ryan wonders aloud to Miller why he cannot visualize the faces of his dead brothers. Their missing faces mark how Ryan's brothers are lost to him. Faces individuate; they signify human particularity. By effacing the Germans at Normandy, the film suggests how Nazism suppresses individuality and especially subordinates private to public.

37 This is the main contrast between America and Nazi Germany that Saving Private Ryan articulates. J ust after the battle on the beach, one of Miller's men - Caparzo - takes from a dead German soldier a Hitler Youth knife. The Nazis even intrude on childhood playtime. Compare this with Caparzo's attempt to defend a French family caught in the middle of a skirmish. Its home has had a wall blown off, and the family's father entreats Caparzo to carry the family's young girl to safety. Contrary to Miller's order, Caparzo accepts the assignment because the girl reminds him of his niece and "it is the decent thing to do." As a result, he is killed by a German sniper. Thus Nazi Germany scores a small victory and America suffers a loss, because the Nazis do not respect the family whereas the Americans show 
great sympathy for it.

38 In Nazi Germany, public swamps private, whereas America skirts the reverse mistake. In America, the private is treated as sacred, and so-called public activity is often private at its core. Consider the Bill of Rights. It regulates what government can do in private realms. Indeed privacy becomes a right implied by the Constitution and a priority defended by the film. Miller guards so effectively the details of his private life - his occupation and origin - that his soldiers create a prize for whoever unearths these secrets. In the quiet moments before the battle of the bridge, Ryan asks Miller about his wife and home. The conversation has seemed intimate, but Miller will not go there. Instead he makes a point to say that these matters are just for him. For the German side evoked by the film, to save Private Ryan as an individual or protect personal privacy is unthinkable.

39 After breaking through the German defenses, in large part because of Miller's leadership, the Americans quickly seize the advantage. A detachment lays siege to one of the fortified bunkers. The Americans hurl a grenade through an open door then point their guns at the doorway. Almost on cue, a German soldier runs through, in an act of pathetic futility, and is immediately shot. Another does the same thing and meets the same end. Then Americans drive Germans down the length of a trench and into an ambush where they are shot like fish in a barrel. There seems to be no Captain Miller for the Germans, who show none of the resourcefulness of the Americans when they were apparently hopeless situations.

40 Now that the Americans are on top, however, they also display a vice not evident in the Germans. The American virtue of resourcefulness seems to have an evil side-effect: bloodlust. After the two Germans are killed trying to escape the bunker, the Americans shoot a flame-thrower into the open doorway. Flames explode through the opening on the opposite side, and Germans on fire jump from it. But an American positioned to shoot the burning soldiers and put them out of their misery tells his comrades, "Don't shoot. Let 'em burn!" Americans give the Germans trapped in the trench no chance to surrender, an offer the Germans probably would have accepted, then the Americans spray bullets into the dead and dying. It takes Sergeant Horvath several attempts to get them to stop. (The Americans do take some prisoners; in the next scene, Miller reports to a commanding officer that twenty-three are secure.) Later two 
Americans toy with, shoot, then mock two unarmed soldiers who were trying desperately to surrender. The Americans do not realize that these were Czechs, who may have been compelled to fight for Germany.

41 The Germans might have become killing machines, but they do not revel in violence as Americans do at times. In killing, the Germans seem detached, mechanically following orders; the Americans are more emotional: some score private gains by killing, some slake a thirst for revenge. For some of the Americans, neither law (following orders) nor public good (victory) is enough. Some inflict as much pain as possible; others take satisfaction in mutilating to dehumanize; still others taunt and torture.

42 The self-motivation of the Americans, even in killing, expresses an unhappy kind of democratic equality. In America, the individual matters and needs a private rationale in order to act with energy and resourcefulness. Democratic citizens think of themselves as the authors of their activities. In war, bloodlust can be one of the side effects.

43 If the German side is more mechanical, and therefore ruthless, it is also more decisive. It does not weigh reasons to act. Any questions already have been answered and forgotten. Yet as walking answers to forgotten questions, the film's Germans are susceptible to the vice of going through the motions. The film shows this with a German soldier captured at the radar site. To endear himself to his captors, he spouts a stream of Americanisms, sings a phrase from "The Star Spangled Banner," declares that he likes America, and concludes, "Fuck Hitler." Although he is trying to avoid execution, we have to doubt that he is talking as a committed Hitlerite.

44 In contrast, the film's Americans are walking questions about unspoken answers. The answers can be summarized as "Uncle Sam Needs You!" The questions, of course, are versions of "Why am I here?" The questioning surfaces in different, innovative, even despicable ways. So individuality and resourcefulness connect in the Americans with indiscipline and lack of unity. The film depicts American soldiers acting under the influence of different, individual reasons that range from religion to revenge, honor to bloodlust, and otherwise.

45 Before each shot, J ackson, the talented sniper, says a prayer that 
casts him as the Lord's instrument. He gripes that his assignment is "a serious misallocation of government resources," because his God-given marksmanship could end the war if he were put within a few thousand yards of Hitler. Etymologically he is the son of J ack, familiar for J ohn, known as the evangelist, the good messenger. At a church where Miller's unit spends the night, J ackson falls asleep as soon as his head hits the pillow: a sign of a clear conscience. Still the film raises doubt about J ackson's answer to the question of war: his belief that he is the Lord's instrument. Toward the end, he snipes at long range from the bell tower of a gutted Gothic cathedral. As he shoots and chants his prayer, a German tank appears below. Slowly and audibly it aims at the heedless J ackson, who dies along with the comrade he was to protect. Jackson's answer to the democratic question of war is at war with American democracy. Arming himself with religious certainty, J ackson can become a threat to his regime. Subordinating himself to God's will, he enacts an absolute subordination of private to public that could eradicate democracy.

46 Horvath collects cans of dirt from the theaters where he has fought. During the film's last D-Day scene, he beckons Miller to look down on the corpse-covered beach with the observation that "it is quite a view." LikeJ ackson, Horvath has a perspective that diverges from public reasons for the war. He has grown attached to it as a trial. His cans of earth record the magnitude of his labors. It is not just dirt he carries; it is "Africa," "Italy," and now "France." He shoulders part of the world because he put it there. After the war, will Horvath be able to put his cans of dirt, his prizes of war, on the shelf? Can he make them remembrances and acclimate himself to political life in America? Or will they symbolize martial virtues that he would enact at home? The danger is that Horvath is ready to threaten his regime by embracing an idea of virtue familiar from Achilles and Rambo.

47 Later, though, the Ryan mission seems to help reattach Horvath to his regime. After Miller and Horvath walk across the bridge, moving from the real to the surreal, Horvath argues for staying because saving Ryan might be the most decent thing they take from the war. To his souvenirs of Africa, Italy, and France, to the antinomian virtue they might imply, he would add Ryan, who will not abandon his post because he will not abandon "the only brothers he has left." Unlike earth from far away, Ryan evokes Horvath's country (public) and family (private). These ideals are much safer for American democracy. As Horvath says, if we save Ryan, "we all earn the right to go home." Horvath now thinks of 
going home, not adding “Russia” or "J apan" to his collection.

48 Mellish, too, has reasons for fighting that are not altogether explained by the demands of national security or western freedom. This J ewish soldier gets a Hitler Youth knife as a souvenir from a comrade, who takes it from a soldier massacred in the trench. The knife comes with a joke about its use in a J ewish religious rite. Later Mellish torments passing German prisoners by sticking his necklace with the Star of David in their faces and chanting "J uden." Likewise he insults "Dagwood Dusseldorf" by shouting that a Rabbi had circumcised his father. Vengeance is on Mellish's mind.

49 Even Miller, the master of in-between, employs a rationale less than public. This is to motivate his men more than himself, but Miller does not present himself as governed primarily by the public realm, even though his conduct shows that he is selling himself short. Twice chided by Horvath for sending his men into harm's way, Miller responds:

(1) "It's the only way of getting everyone the hell out of here."

(2) "All we can do here [if we remain where we are] is die."

He sends men into harm's way to save their lives. For the moment, at least, he is not acting to save Americans back home or American allies. Nor is he acting directly to win the war, earn glory, or secure an honored burial place. As attractive as Miller is, however, we have to wonder whether his motives are strictly private. Have public goods like heroism, virtue, and justice no meaning for him? If he values private life alone, why not order his men to surrender? Even if a German victory would mean an over-regulated private life administered by Nazis, wouldn't that be better than no private life at all. Miller's spoken rationale cannot account for his own conduct during the war. Nor could a country depend on it to generate the action it requires in crisis. An Islamic fundamentalist recently claimed this as the Achilles heel of Americans: "You love life, we love death," he said. But Miller dies to help save Ryan.

\section{Freedom's Other Altar}

50 After the beach has been won, Miller sits next to Horvath. The camera focuses on the tremor in Miller's hand. The battle is over, but the war and its burdens continue. The camera moves up to 
Miller's eyes, and closes on them as Horvath comments on their view of the corpse-covered beach. In a scene that reminds us of the transition from the war memorial to the war, Miller's view becomes ours. Thus the film encourages a mistaken inference that the man at the memorial is Miller, not Ryan. The deception is Machiavellian; the film is as ruthless in guarding its secret or privacy as the Germans were in guarding their beachhead. Preserving the private is worth a lie. As Miller gazes reverently at the beach and agrees that it is indeed "quite a view," we see what he sees. Again the path to the public runs through the private.

51 The beach we see is awash in blood and corpses. Amid the corpses are dead fish. For the sake of country, humans share the same fate as fish: this is a measure of the soldiers' sacrifice. In attending to their bodies, Miller and the film pay homage to these men. Their bodies are not yet ravaged by the elements, gulls do not pick their flesh, crabs keep away. Not even our eyes are free to see the faces of the dead soldiers, because the men lie facedown or turned away from the camera. These soldiers gave their lives and will not be forced to reveal the private anguish of their last moments to public eyes. The music is august yet sympathetic. It suits genuflection and tears.

52 The camera moves down the shore and pauses above a dead soldier. On his back, we read "Ryan S," another step in deception. The scene shifts abruptly from the battlefield to an office floor. Yet the new setting has something military about it. Rows of desks echo earlier rows of burial markers and water obstacles. The desks support typewriters on which a battalion of women labor. The clatter of typing replaces the clatter of gunfire. The music signals continuity. This setting, the film intimates mysteriously, extends the one just interrupted.

53 Above the typing and music, we hear voices. Each, we soon discern, narrates an excerpt from letters being typed to send to the families of all soldiers killed in action. A different voiceover for each letter communicates efforts by the U.S. Government to personalize the letters in order to ease each family's loss. The contents, like the voices, are distinctive. One letter refers to a soldier's dangerous and important mission. Another talks of the comrades who valued a family member's leadership. A third celebrates a soldier's patriotism. Each letter mourns an individual, and each addresses a named individual. Everything about the letters implies an appreciation that some general explanation of national purpose would not assuage any particular 
family in its grief. Public news about why the country fights or how it fares does not equal or even encompass private views of a loved one's death, so America constructs an agency whose public function is to minister to each family at least somewhat individually.

54 Still the scene is ambiguous. The women mechanically type words of sympathy written by someone else, the letters pile up, and the clichés accumulate. Is the film mocking government efforts by lampooning mass-produced sympathy? A seemingly mechanized attempt to console bereaved families by letter might be doomed to fail, because the connection between senders and receivers is too remote. Can democracy as a distant abstraction offer true consolation to families of flesh and blood? If not, the attempt to console families also could be faulted for leaving fewer resources to fight the war, resulting ironically in more families that lose sons, fathers, and husbands.

55 Saving Private Ryan emphasizes the military's necessary indifference to individuals. Its last letter says, "we fully understand your desire to learn as much as possible regarding the circumstances of ___ 's death, but ..." Fittingly the narrator's voice becomes inaudible. If a family's agony can be diminished only by classified details, the family must swallow its pain. Consolation will not come at the cost of the public mission: winning the war. Another example of indifference to individuals occurs in the siege of the German bunkers. Miller orders the men at the sea wall to gather weapons and ammo from the beach. Some who lie there are alive and need care. One soldier responds to Miller's order by taking ammo from a comrade lying prostrate because he is missing a limb. He pleads for help, but is ignored and left behind.

56 Although Saving Private Ryan graphically depicts America sacrificing individuals for the greater good, it also shows America striving greatly for individuals. On the beach, we see ammo counting for more than a man, but we also see army chaplains giving soldiers their last rites in the heat of battle. In America, individuals may become the greater good; the private gets support from the public. Saving Private Ryan locates America, like Captain Miller, in-between. Overall that is how the film handles the sympathy operation. It bathes the drab military office in golden light, while it shows typist cheeks red with exertion and emotion to add touches of the heroic. 
57 Amid the women typing away, the camera settles on a nondescript woman. She sits at a desk without a typewriter and compares two letters. Something has caught her eye. Others might be going through the motions; she is not. In tune with her field of operations, she is the Captain Miller of her unit, and Private Ryan's survival will depend as much on her as Miller. After consulting the two letters, she walks to another desk with a pile of letters, extracts one, and compares it with the other two. The camera pulls back to show her bound energetically, three letters in hand, into the office of a man in uniform. We register now, if not before, that the woman wears no uniform: evidently she is a civilian working for the military.

58 Next we see a relay race up the chain of command. The woman and the officer, who now holds the three letters, walk hastily into the office of a captain to tell of the woman's discovery. In a flash, those two men are in the office of a colonel who stands behind his desk. The woman has dropped out, but her intelligence has the military working at top speed. The captain places a folder thick with documents on the desk then informs the colonel that "these two men died at Normandy yesterday" while handing him paperwork on both. The colonel reads the names on each document: "Sean Ryan," "Peter Ryan." The monotone and unaltered expression suggest he is unmoved. Perhaps the fact that he is missing an arm has hardened him. The captain tells the colonel of a third man who died in New Guinea last week and hands over the paperwork. The colonel reads, "Daniel Ryan." Still the colonel stands expressionless. The captain reports that the three men are brothers and their mother will be receiving three letters in the afternoon to notify her of their deaths.

59 Now the colonel sits. He is moved. On his scale of private suffering for public good, three dead sons on one day tops one left arm. What mother would not forfeit a left arm to save her three sons? But the captain adds that there is a fourth brother, J ames. Dead or alive, he is fighting somewhere in Normandy. Now we understand the folder. The woman with three letters had pieced together the news of the dead but not the living. To find out about the fourth brother, the captain had to do some digging. In little time, he had learned about this last brother and his latest assignment. The military for a democracy fights always on two fronts: private as well as public. This is the burden and strength of American democracy. The colonel tells the captain to come with him. 
60 The scene changes abruptly. A black car with a silver star on the side heads up a dirt road to a farmhouse where a woman washes dishes. The kitchen is simple but angelic, with a rosy glow. Outside the kitchen window hangs a pennant with four stars, one for each son. As we watch the woman through the window, it reflects the black, hearse-like car. Seeing the car, the woman is stunned yet stoic. As if to give her a moment to compose herself, the camera cuts outside to a wonderful view of the farm. A huge wheatfield blows gold in the sun. Back in the kitchen, the woman turns to meet the occupants of the black car.

61 The kitchen is where the woman fed her four sons. Its light is almost supernatural. The film arrays the whole home and farm in glory, giving grandeur to the private realm. The farm is lush and beautiful; stomachs and eyes could feast for a lifetime on it and it alone. Living here, who would need a public realm? It brings honor, but at a high price, as the woman already fears. As she reaches the foyer, the car commands the driveway like an invading force; its contrast with the farm could not be starker. The star marks it as a military vehicle. Stars capture the allure of military and public life. They shine forever, sometimes worshipped as gods; but they only burn in the dark, the night, when nothing grows. They link to death. The black car comes with news of the honor her sons have earned. She will receive it like the plague.

62 The woman goes onto the porch. You do not wait in your home for invaders; you do not want enemies to get that far. As an Army chaplain emerges from the car's back seat, the woman staggers. She knows what this means. Yet she really has no idea. She fears that one son is dead. How can she suspect three? The music is from the vista of corpses at Omaha Beach. On a farm in Iowa, DDay has just felled another victim. ${ }^{2}$

63 In the heartland, the private wound is horrendous; but like some cosmic surgeon, the American military reaches into the wound to stanch the bleeding. Mrs. Ryan was about to get three letters about three dead sons. But the news comes in a different form: an Army chaplain to provide personal support. We surmise that this is due to the anonymous civilian woman, perhaps herself a mother, embedded in the office of the U.S. Army Chief of Staff. With the Iowa mother on the porch floor, we hear a godlike voice exclaim, "God damn it!"

64 The film cuts to the office of the voice. General George C. 
Marshall is meeting with the colonel, the captain, and another officer. The private, civilian worker has redirected the public, military juggernaut. It has focused on ending a totalitarian regime; but because of her, it also will attend to saving the last surviving son of the Ryans. The U.S. Army Chief of Staff is now working for Mrs. Ryan. The story is fiction, but its inspirations presumably include the Sullivan sons of Iowa who all died at sea in the Second World War as well as the Marshall Plan that bears the General's name for saving public life in Europe by saving its private economy.

65 Marshall is concerned about Mrs. Ryan's surviving son and asks if his whereabouts are known. The colonel says that James parachuted into Neuville, so a search should begin there. As we move up the chain of command, and officers higher in rank take charge of the Ryan case, information gets more specific. In this episode, power is measured by private service: what can be known and done about the Ryans of Iowa. When Marshall ends the scene by saying that the "boy is alive" and "we are going to send some people to find him to get him the hell out of there," we might need reminding that Marshall is only human.

66 Before Marshall makes that determination, his aide argues against it. One trouble is that airdrops often miss their targets, so Ryan could be anywhere within a wide radius. The larger one is that trying to retrieve Ryan from behind enemy lines is almost certain to mean more KIAs: more sons lost by more families. A rescue mission to serve Ryan and the private realm will cause more injury and divert resources from winning the war. The dissent seems sound.

67 With a hint of impatience, however, Marshall cuts him off and retrieves a bookmark that turns out to be a letter valued by Marshall. It was written by Abraham Lincoln to a Mrs. Bixby of Boston. In the Civil War, she had lost five sons. Marshall begins to read the letter aloud but soon is reciting it from memory. The letter leads immediately to his order that J ames be found and brought home. Other than the letter, Marshall ignores the dissent and offers no explanation. He treats the retrieval as self-evident in its justice and priority.

68 At most, Lincoln's letter ties obliquely to Ryan. It does not rebut the dissent, but simply says how excessive suffering by particular families concerns Lincoln. Plainly he did not write all mothers who lost sons. Yet he does not say that the Republic erred in 
sending Mrs. Bixby's five sons to their deaths, and he attempts to offset her loss by reminding her of the public good served by their sacrifices. If Lincoln would have Mrs. Bixby give five sons to keep the Republic together, why would Marshall not have Mrs. Ryan give four sons to defend it from annihilation?

69 Toward the film's end, when it is clear that Mrs. Ryan will get J ames back, General Marshall narrates a letter to Mrs. Ryan in which he quotes from Lincoln's letter to Mrs. Bixby. Lincoln kept the Republic together, but he suspended habeas corpus and, in the minds of some, sacrificed too much of private value on the altar of public need. As a disciple, Marshall redeems him. Little ambiguity remains to Lincoln's letter after Marshall coöpts it. Saving Private Ryan fulfills a mission dear to Marshall and establishes a precedent for his successors. The Marshall letter may remind a future general or president of the sanctity of the private realm and especially of the family, even in war. It also shows again the film's uncanny ability to meld public (a new precedent for the country) and private (satisfaction for Marshall and Mrs. Ryan).

\section{Losing Captain Miller}

70 Marshall's decree sends us back to Omaha Beach, where the C.O. tells Miller of his new mission. Miller receives the orders dutifully but with a touch of cynicism. The C.O. says only that they "come straight from the top." To Horvath, though, Miller reports "a public relations mission." We know better, but Miller seems to regard the mission as a detour from the military campaign. Given Miller's rationale at Omaha Beach, this actually would not be true. The new mission is a logical extension of the old, at least as Miller had construed it. This helps us see that the film puts Miller's private, democratic rationale on the operating table. The procedure almost kills it, and Miller himself does die at the bridge; but his rescue of Ryan also saves his rationale for democracy, and that makes all the difference.

71 Horvath does not worry about becoming fodder for the newspapers; instead he is aghast that Miller's company has been reassigned. For Horvath, this is comparable to Agamemnon confiscating Briseis from Achilles. Miller disagrees. The company is the property of the U.S. Army, so it is not exactly being taken away from Miller. Yet Miller's leadership has given him a special stake in the company, and the new mission induces in him some sense of forfeiture. On the other hand, Miller can 
pick men for the Ryan mission, and he tells Horvath who he wants. When the unit lacks a speaker of French, Miller looks for one as Horvath readies the men.

72 Next we see Miller in the campground of his new recruit, "Corporal Timothy E. Upham." Naming the new recruit fully from the start marks him as important, for Saving Private Ryan is tightlipped about names. We have just learned that Miller's first name is J ohn, and we do not get his full name until the film's end. We never learn the first names of J ackson or Mellish, while Wade and Caparzo have to die before they are so distinguished. Miller makes known his interest in Upham's German and accent as well as his French. Leaving Horvath, Miller had said he was searching for an "interpreter," not a translator. Miller had even indicated that the French of one of his regular soldiers (Talbot, who turns out KIA) would have sufficed. But now Miller wants someone who speaks German, as well as French, with good accents. Is the oddity in the editing or the plot? Something peculiar is happening.

73 Upham is not eager for a mission to Neuville. He knows it has "Germans, lots of Germans." He says he has not fired a weapon since training and has no combat experience. As a soldier, he merely reads maps and translates. He asks Miller if he can bring his typewriter, clumsily drops his gear, forgets his helmet, and does not know how to carry a rifle. Upham is a soldier in theory more than practice. He later discloses that he is writing a book on the "bonds of brotherhood that form among soldiers," so he is like several others in his new unit in having his own private rationale for participating in the war. It completes his education, and though it is not the education he expects, his ambition is realized.

74 Such considerations make it hard to see why Miller recruits Upham, and the film presses this question. At the radar site, Upham pleads the case of a German soldier who eventually shoots the bullet that ends Miller's life, and Upham's battlefield ignorance costs the unit dearly in other ways at the bridge in Ramelle. Knowing Upham is not ready for combat, Miller bears responsibility for these costs. Perhaps this is why, in the end, the film seems to absolve Upham and blame Miller.

75 The unit heads for Neuville, and the mission draws criticism from the first. Reiben wonders why eight should risk their lives for one. Democracies sacrifice life and limb for the many, not the one. America's foes are the soldiers who seem to fight and die for 
one man, a Führer or an Emperor, and this makes the enemies worth fighting. Has a note of Nazi fanaticism crept into the American campaign? Wade, the unit's doctor, reminds Reiben of Mrs. Ryan; but Reiben replies that all soldiers have mothers. Why should another soldier's mother suffer to spare Mrs. Ryan?

76 Wade does not respond, so Miller asks for volunteers. Upham answers the call by quoting Tennyson's Charge of the Light Brigade: "Theirs not to reason why, / Theirs but to do and die." Wars cannot be fought without respect for orders. Yet "to reason why" is crucial for democracy in an American mode. To save the mission, Upham would forfeit its justification: being free to reason why. In fact, his response is a rallying cry of fascists. At the camp where Miller first meets Upham, he accidentally grabs as his gear a German helmet kept as a souvenir. Perhaps the slip is Freudian.

77 Open discussion of the mission's validity emboldens the pious and polite J ackson to join in. Reiben defends democratic equality, but J ackson defends public good. He faults the mission, not for focusing on the one, but for focusing on the wrong one. Not Ryan but J ackson should be the focus. With support, his God-given talent could single-handedly end the war, giving sons back to Mrs. Ryan and many other mothers. J ackson's specific example may be ludicrous, but his overall reasoning is not: arguably the best way to save anyone's family is to end the war, by ignoring for a time all particular families.

78 The tone has been light, but Reiben will not let go. He dismisses J ackson as a "bumpkin" then presses for Miller's thoughts on the mission. Miller jokes that he gripes up the chain of command, not down, but eventually he accedes to Reiben's request by imagining a dialogue with a superior officer. The artificiality of Miller's defense of the mission amuses everyone and ends debate for the moment. But when bodies start piling up, the laughing yields to tears, anger, and violent dissension.

79 Arriving at Neuville, Miller's men meet American soldiers desperate for reinforcement then discouraged to learn that Miller's unit has a different mission. Nevertheless they agree to help learn if Ryan is in the town, and they send a runner to gather intelligence. He is soon shot; the mission to save Ryan claims its first victim. Miller's men make their way through town, and reassemble at the house of the French family whose wall has been destroyed. 
80 When the father begs Miller's men to carry his young daughter to safety, Miller tells the father that they cannot help and she would not be safer with them. Upham translates to facilitate their communication. Despite Miller's reasons and against his orders, Caparzo accepts the new mission. Rather than persuade Caparzo that he is misguided, Miller tells him to obey orders, and chaotic shouting ensues: the father bellows commands of obedience at his daughter, Horvath yells at Caparzo to obey Miller, while Miller shouts at Caparzo and Upham that responsibility for the girl is too dangerous for all involved.

81 In the chaos, Upham's talent for logos pays no dividends. He is not a neutral transmitter between Miller and the father. He sympathizes with the father, and his battlefield inexperience leaves him ignorant of the risks. Has Miller put too much faith in logos by recruiting Upham, who is all logos all the time? Or has Miller failed to take the Ryan mission to heart, therefore giving too little thought to Upham's recruitment? Seconds after the wavering Caparzo submits to Miller's order, a sniper kills him. Standing over Caparzo's corpse, Miller later orders Upham to fill canteens with water, apparently as a punishment. Upham contributes to Caparzo's death, and this exposes Miller's mistake in taking Upham. Before the men resume their trek through Neuville, Miller orders Horvath to stick with Upham. Horvath says that he "will wear him like underwear." But it makes little more sense to "wear" Upham through Neuville than to carry the French girl through it.

82 Although Upham contributes, Caparzo instigates the fiasco. What can we make of his act and its result? Miller's men are to defend a family, but not this one. Family-friendly to begin with, Caparzo cannot refrain from generalizing to cast himself as the defender of families everywhere. It is an easy mistake to make, for it is not easy to dismiss the father's demand for help, once we agree that help is owed Mrs. Ryan. France is an ally of America, and this family might have suffered multiple casualties. Fighting the war not just to win it but to limit suffering by individual families makes it hard to know where to draw the line. This might explain Miller's uncharacteristic imperiousness. When a situation makes no sense, persuasion has no purchase, and orders must suffice. Not even democrats can fault Miller for telling Caparzo, "we're not here to do the decent thing. We're here to follow fucking orders." The problem for Miller, as we know by now, is that he does not operate this way. The mission is driving him to war with himself; and as they pursue it, his hand tremor becomes more 
and more noticeable.

83 After the men pay their respects to Caparzo, they move forward until they reach an alley of sorts where a soldier finds debris that let him sit to fix his ill-fitting boots. But he tips a large piece of wood into a brick wall, caving it in and exposing German soldiers who immediately assume firing positions. A stand-off ensues, with Upham at its center. He is the only one of the Americans who speaks German. Yet he cannot prevent violence, because the two sides are beyond reason's reach. Unbeknownst to the German soldiers, other Americans enter the scene and end the stand-off with machine guns.

84 That night, when Miller and his men bunk in a church, the day's events make themselves felt. Miller talks of earlier characters he has commanded. A soldier comes to mind who could walk on his hands faster than his legs and would urinate a V on his comrades' jackets - for Vecchio and for victory. Miller admits the pain in putting his men in harm's way. Their deaths burn indelible marks in his memory, and Miller also knows the precise number he has killed: 94. Appreciating the particular personalities of his men leaves Miller more affected by their deaths. That he treats his men like family is a reason they love him. To deal with their deaths, though, he must resort to rationalization: by sending some to their deaths, he saves many more.

85 Every death saves many lives: Miller's multiplier. We saw it at work on Omaha Beach. Miller leads his men into machine-gun fire to create an exit that enables as many of his men as possible to escape. Had he stayed aloof, treating his men as mere parts of a mission itself a mere part of the effort to win the war, Miller might not be so vexed. Or had Miller told himself, as Marshall later writes Mrs. Ryan, that they are fighting tyranny and oppression, maybe he would not need his multiplier. But Miller is not moved by such abstractions. They would make it too easy for Miller to ignore the welfare of his men. They would keep him from taking pleasure in their company and humanity. They would justify treating the men as mere parts rather than as individuals, and this he will not do. For Miller, getting his men through the mission is always a goal. That is why he can estimate how many lives he has saved. The trouble is that the current mission does not fit Miller: it leaves his conscience dangling in the wind.

86 After speaking with Horvath, Miller walks among the men. 
Upham summons him, and he asks how Upham is. Having made it through his first day of battle, Upham fantasizes that the war is good for him. At war for years, Miller is skeptical and asks how. Upham responds by quoting Emerson, though not by name, on the character-building effects of combat. Miller then outs Emerson and says the point is skewed towards the bright side. The idea that Upham has borrowed from Emerson is too general. It does not persuade Miller, who knows a lot more about the experience of this war than either Emerson or Upham.

87 The two are polar opposites in name and view: Miller on the ground, Upham in the air. Upham suggests that the interpreter is from the hamlet of Up; and even his first name points there, since Timothy means God-honorer. Miller points down to the ground by naming a stone used to grind grain. Both Miller and J ohn have been more common as names. Unlike Miller, Upham likes abstractions. He is quick with quotations from big names, falling back on dicta of great men and set in motion by them. Has Emerson given him a reason to look forward to the war? Writing a book on the bonds of friendship forged in war, Upham wants in theory what Miller has in practice.

88 Yet theory and practice can stay far apart. For Miller, war is a necessary evil; for Upham, a positive good. Miller would minimize the suffering of his men; Upham treats fighting and suffering as chemotherapy: they can heal, but they also can kill. For Upham, the price is worth paying. Upham's rationale for the war seems indifferent to side: he might as well be fighting for the Reich. When the German saved by Upham fires the shot that kills Captain Miller, Upham lies right beside the German. From the sky, Upham and the German could be of the same army.

89 After Miller and his men fail to find Ryan in Neuville, a tip leads them the next day to a camp of American stragglers. There they sort through a bag of dog tags in search of Ryan's. A callous game of poker takes shape, with tags substituting for cards, until Wade ends it because comrades of the deceased can see the "cards" as Miller's men deal them. Miller seems amused then, once caught, embarrassed. The mission makes him increasingly indifferent to Ryan, his mother, and others. Even Miller notices that he is not the same.

90 At the camp, Miller learns that Ryan was assigned to guard a bridge - prime real estate, as Miller says - at Ramelle. On the way, Miller and his men run into a radar site guarded with a 
heavy machine gun recently used to kill Americans. Miller decides it must be disarmed before it can kill again, but he is alone in this. Reiben, whose name is German for rubbing or causing friction, wants to go around the site. He neither wants to save Ryan nor fight the war. Mellish concurs, arguing that disarming the radar site is irrelevant to their mission. Miller responds that their mission is to win the war, and Mellish is duly chastened. At the previous camp, he showed his necklace of the Star of David to passing German prisoners and paraded himself as avenger of the J ews, but he no longer seems to care about J ews or Americans.

91 Although they take the radar site and a prisoner, the unit loses Wade, its only doctor. For Miller to put Wade in harm's way here is curious. At Neuville, Miller reprimanded Wade for sticking his neck out: as the only doctor, he should know better. But now he is expendable? Wade does not carry a gun, leaving him of little value to the offensive, and this whole assault is comically tragic. While the unarmed doctor runs into gunfire, the armed translator hides behind a cow and views the action through a scope. Again we have to wonder about the mission's effect on Miller.

92 Whatever the effects on Miller, the effects on his men further challenge Miller. Apparently the men do not support their mission because it requires them to risk their lives for one man, and they seem no longer to support their country and its mission because it privileges Ryan. This is reinforced by what they find at the straggler camp: twenty-two killed in an effort to save one general. Their odyssey seems rigged to corrupt them and to test Miller. How much easier it could be on Miller had Caparzo and Wade survived: both were family-friendly and might have helped Miller maintain unity. Instead he must operate with the cynical Reiben and Mellish. The film is putting Miller on trial. The question is why.

93 After the dust settles, Miller steals a moment alone to sob uncontrollably. Now that the Miller multiplier no longer supports him, the captain behaves like a civilian in the face of death. Meanwhile Reiben, Mellish, and J ackson can barely wait to execute the prisoner in revenge for Wade. A heated debate follows with Upham who takes the German's side. Giving water and comfort to the prisoner as he digs graves for the killed Americans, Upham argues that the rules forbid the execution of enemy combatants who surrender. The argument is too abstract. They are not equipped to hold a prisoner. Perhaps this should 
have dissuaded them from storming the site. But if they simply let the prisoner go, they will have disarmed the radar site only to send an enemy combatant back into the field of battle. What if he knows the location of stashed weapons or a German convoy? He could sabotage their mission and the missions of others. Upham had not participated in the assault but watched it through a scope. From a distance, everything looks black and white. Morality is easy in theory. When Miller sides with Upham, Reiben pulls out of the mission. Horvath threatens to shoot him, and all hell seems about to break loose.

94 Miller is impossible to dislike, but Reiben has a point. At Neuville, the imperative is to follow orders, even though they pursue a private good rather than the public one of winning the war and even though Caparzo disobeys on behalf of a family. At the radar site, winning the war suddenly supercedes the order to save Ryan. With the prisoner, however, winning the war takes a backseat to international law - even at the expense of the unit's security, America's security, and the security of law everywhere. For a victorious Germany is not likely to accept precedents of international law. Reiben hits the nail on the head when he tells Upham that "your rules just left with your new friend." It is ludicrous to think that the prisoner will turn himself in to Allied forces just because the rules mandate it or Miller orders it. The "rules left with him" means they are in the prisoner's possession, his to obey or not. This is to say that he is not bound by rules. For rules that rely on self-enforcement are rules in name only, especially when individuals or regimes show no propensity to observe them.

95 Again Upham occasions a crossfire. Had he not pressured Miller to release the prisoner, Miller (who has lost his grip somewhat) might have acted differently, and the radar trouble might have been avoided. Miller might even have stumbled on a middle solution between freeing the prisoner and executing him.

96 In the film's last act, Upham's "new friend" kills both Miller and Mellish; and in both instances, Upham spectates. The killing of Mellish is especially gruesome. Sprawling on the floor, wrestling with the German, Mellish takes out a dagger. (Is it the Hitler Youth knife?) The German wrests it from his hand then slowly plants it in his heart. As Mellish pleads for his life, the German looks into his eyes and appears to taunt him. As a bystander, Upham is an educated moral posturer. He speaks eloquently of morality, but lacks the sense and fortitude to act. Such 
bystanders bear responsibility for Hitler's crimes, as Upham does for Mellish's murder. They make private peace christened in the blood of others. When Upham talks with Mellish, is it for friendship or the book? Upham is much less than a friend, for friendship and morality require more than words.

97 Near the film's climax at the bridge, Upham finally figures this out. After he watches the ex-prisoner shoot Miller, Upham's expression changes from fear to cold fury. When American planes arrive to send the Germans running, he springs up and orders several Germans, including the ex- prisoner, to halt. Upham's "new friend" seems not to take him seriously. Upham could make him a prisoner again but executes him instead. Bonds of friendship forged in war inform hatred of the enemy, and they provoke Upham to his first soldierly act, questionable as it is. Whatever we may think of it, the film depicts this as the beginning of Upham's education. Reason is not enough to govern relations, and esprit de corps involves enemies.

98 Back at the radar site, though, Miller does something no one expects. To stave off disaster and save the mission, he discloses where he comes from and what he did at home. This mystery has long intrigued the others. At this moment of crisis, Miller sacrifices his private life for the public good. (To say this is to assume that saving Private Ryan, a mission that originates with the Chief of Staff, serves the public good; whether this is true is the film's focal issue.) In coming clean, Miller reminds the men of something they share: curiosity about his private life and yearning for their home. The war and its orders are nothing to fight about; home is the important thing. The reward is a return to home, so they should perform their mission regardless of their contempt for it. Distracting the men from their feud and reunifying them, Miller coyly puts the mission back on track, bringing them all closer to home. In effect, Miller suggests that they should not feel misused by the military because, in returning Ryan home, they do the same for themselves. They get what they give.

99 In a further attempt to solidify the company, Miller expresses the utter indifference for Ryan that most of them share. "Ryan is just a name," he says. In responding to Reiben's earlier critique of the mission, Miller had constructed a speech for a superior officer, and it talked about the welfare of Mrs. Ryan and her family. But now Miller turns away from them. The enemy of abstractions, Miller makes Ryan into one. Ryan's family is irrelevant, and the 
man who might speak for her lies buried because of Miller's bungled assault on the radar site. Wade was the one who urged thinking about Ryan's mother and, in the church, reminisced tearfully about his own mother. In the reunifying speech, Miller worries about how much the war has changed him, ruining him for home. Wade could have told Miller how right he is. Who will save the captain?

\section{Angels on Shoulders}

100 In the next scene, Miller's unit finds Ryan and tells him its reason for coming. But we soon wonder who is saving whom and who needs it more. Ryan wants to stay put. He has tears for his brothers, but he does not weep for home. This is Miller's war cry, not Ryan's. Having lost his brothers by birth, he will not abandon "the only brothers he has left." He will not use his private loss to forsake his comrades and country in their time of need.

101 The orders do not make sense to him, says Ryan, and therefore he will not obey them. He turns Tennyson right side up. He "reasons why" so that he may "do and die." He manifests an American virtue exactly when America most needs it. Had he just followed orders, all might have been lost. Ryan is not monstrously dedicated to the universal; he is not indifferent to his mother's suffering. But he says that she will understand. If she knows the situation, she knows that he could not leave. She knows him, not as a fanatic patriot, but as a good son. She did not raise him to abandon friends but to stand by his brothers, and these are the only "brothers" he has left. In using the vocabulary of the family for his devotion to his comrades, Ryan implies that friendship and patriotism are grounded in experiences that families provide. Had he not felt the bonds of loyalty at home, would he really know what brotherhood is?

102 Miller has become confused. Compare his conduct now to what he did in Neuville with "the wrong Ryan," J ames from Minnesota. (When Miller says at the bridge that Ryan is just a name, he is wrong even about himself, because otherwise the Minnesota Ryan would suffice.) With the Minnesota Ryan, Miller enlists the help of the commanding officer and prepares this Ryan by having him take a knee. But with the right Ryan, Miller does none of this - although the Iowan, too, has nearby comrades who would be glad to help. Instead Miller's approach is ham-handed, and Ryan responds with a barbed question: "You came all the way here to tell me that?" Miller shows little concern for this 
Ryan, who is moved by the fact that two soldiers died trying to find him. He asks for their names; and when Caparzo's does not register, he asks for it again. Showing little humanity, Miller falls back on the principle that orders must be obeyed, even as he violates them in spirit. The orders imply that some deaths can count more than others, but Miller ignores this.

103 Ryan, not Miller, thinks as an individual. Miller's eventual effort to address Ryan as a human amounts to the merest of words, for Miller repeats what he had earlier imagined griping to a superior officer. Miller acts as a preprogrammed automaton. The hero of the in-between has become an abstraction.

104 When Ryan refuses the orders, Miller is flummoxed, and for good reason. He cannot do what Horvath threatened for the mutinous Reiben. A mission to bring Ryan home must not end in shooting him for disobeying orders. The situation requires Miller to start thinking again, and return to himself. Ryan leaps over sandbags to resume his post, leaving Miller on the bridge with his head bowed in reflection. After a moment, Miller nods his head up and down repeatedly and begins to walk across the bridge. Horvath follows to ask what his orders are. Miller says, "Sergeant, we have crossed some strange barrier here. The world has taken a turn for the surreal."

105 So it has. The mission to save Ryan cuts off Miller from himself and his country. Ryan reattaches Miller to both by making sense of Miller's orders. As Horvath says, Ryan is worth saving. He is only one person, but he represents the best that America has to offer. Ryan is a public good all to himself. By saving him, Miller's unit serves the public good. Because Ryan will not relinquish his post, the only way to save Ryan is for the men to help save the bridge, as "solid gold real estate." Public and private become so intertwined for America as a democracy that it is hard to know where either begins or ends. Neither yields to the other; instead the film reconciles them.

106 In return for Ryan saving Miller, Miller saves Ryan twice: first from the Germans then from the Americans. After Miller's preparations are made, but before the Germans come, he and Ryan talk. Ryan confesses that he could never imagine doing for a living what he hears Miller does. Ryan and his brothers were mischievous in school, and he would not want to be on the receiving end. Miller recalls teaching a thousand kids like Ryan, kids who are not serious students. They do not think carefully, 
submitting to dictates of reason rather than spur-of-the-moment whims. When the serious business of war is over, and the situation no longer focuses Ryan's energy, will he revert to a frivolous American? Will he confuse license with deliberative freedom, as Miller has seen a thousand times before? With his last breadth, Miller tells Ryan to "earn it." Ryan must merit the sacrifice. Through Miller, the film shows how democracy grants freedom but its individuals must remember that freedom does not just fall to Earth from some hamlet of Up. So Saving Private Ryan attempts to save us for public action.

107 It also attempts to protect us as private individuals from the overzealous application of Miller's call to arms. The exhortation to "earn it" could encourage crusades. While Miller talks to Ryan, Reiben tells Mellish, Horvath, and Upham about a gift before he went to basic training. His super's buxom wife lets Reiben, whose mother owns a clothing store, to dress her in a bra much too small. As Reiben says, "she was pouring out of this thing." Seeing that Reiben enjoys the show, she takes his hands and places them on her breasts. "Richard," she says, "if you're ever scared over there, think of these." Public sacrifice has rewards in private, as well as public, affairs. Lest we miss the point, the film has Reiben say that he "had a hard-on like the Statue of Liberty." As long as we are free to make the Statue of Liberty a metaphor for erection, we can escape zealotry.

108 Reiben reminds us that it can be good that, in America, liberty becomes the liberty to pursue pleasure. The world has less to fear from millions of windsurfers than millions of moral zealots. Yet Reiben also embodies a challenge. He, too, like Miller, Horvath, and Upham, has something to learn; and he learns it at the bridge.

109 When Ryan admirably resists the orders that would carry him to safety but leave the bridge and his comrades more poorly defended, Reiben intervenes. He calls Ryan an "asshole" and tells him that two men died trying to find him. Reiben vents his anger at Ryan just when Ryan defends his own comrades. The principle that spurs Reiben's ire also provokes Ryan's resistance. For Reiben, principles are fuses for anger, not ideals to honor. Principles pit Reiben against others rather than tying him to them. In a further bid for Ryan's obedience, Miller goes corny, telling Ryan that insubordination might mean his mother gets another "folded American flag." Reiben rolls his eyes in disgust. He respects the flag no more than the Statue of Liberty, and this 
suggests that Reiben's dedication to American principles is not a dedication to America: always a possibility for a democracy of individuals. When the country needs him, Reiben can be missing in action. He no sooner hits the water on D-Day than he drops his rifle, and he wants to bypass the radar site. Horvath calls Reiben a coward who doesn't know how to shut up.

110 Nonetheless the film features Reiben and his point of view, particularly at the bridge. As Ryan swears that he will not leave the bridge and his "brothers," we see him from Reiben's perspective. When Ryan bounds over sandbags to resume his post, we see from Reiben's face how Ryan absorbs him. Ryan does by nobility what Horvath could not do by threat: Ryan shuts up Reiben. Eventually Ryan makes Reiben a believer: in his mission, when their eyes meet as the fighting begins, and in his country. In the battle at the bridge, Reiben fights valiantly and effectively. He single-handedly disarms a piece of German artillery, and he risks death to save Miller, Ryan, and Horvath. If Reiben was a coward, he is no longer. Ryan has stirred Reiben's idealism, focusing his energy for his comrades and against the Germans. After Reiben rescues Ryan from a tank shot, Miller ignores Reiben to ask Ryan whether he is all right. Reiben takes no umbrage at the slight; instead he makes light of it with a hilarious aside. Saving comrades and the bridge are his causes now, and he fights vigorously for them.

111 Reiben is a peculiarly American or perhaps democratic phenomenon, which probably is why the film pays him so much attention. America has turned him into an archangel of equality, ironically causing him to lose respect for America. The back of his ranger jacket lets the world know he is from Brooklyn. The impossibility of perfect equality leaves the democratic avenger with a causus belli - or a reason to withhold support. The democratic avenger may have a point, as Reiben does when he argues against the Ryan mission, but attention only to a pet cause can involve the democratic avenger in hypocrisy. His contempt of country can weaken his country's ability to defend his principle or any others. Like Reiben's therefore, his activism is tinged with selfishness. A democratic avenger inflates himself by taking the air out of his country. Reiben is a private man masquerading as a public man. When America's welfare threatens his existence, he becomes all private.

112 The Reiben problem is difficult for democracies because attempting to solve it can easily make it worse, and those who 
campaign against it expose themselves to the affliction. To see this can make it easier to appreciate the cure prescribed by Saving Private Ryan. In rebelling against orders, Ryan parallels Reiben. Reiben rebels in order to pull out, whereas Ryan rebels in order to stay put. Despite all he has lost, Ryan braves the fire on behalf of his country and comrades. His example enchants and chastens Reiben. Ryan shows the stuff that distinguishes good Brooklynites, pressing Reiben to recognize that his attachment to Brooklyn is less about locales than ideals. Ryan's nobility does not fit Nazi Germany, but it finds at home in parts of America beyond Brooklyn. Although the virtue that Reiben sees in Ryan is not quite a national creed, the nobility evidenced by this stranger from Iowa will make Reiben think twice before smirking against an American flag.

113 If Upham enacts dangers of abstract moralism, Reiben embodies dangers of spirited individualism. The battle at Ramelle redeems both. Besides Ryan, these two men are the only survivors of Miller's unit. Their vices should not be eradicated but reformed, producing virtues that American needs. The battle of the bridge at Ramelle supplies this reform. Miller crosses the bridge while saying "the world has taken a turn for the surreal." He is more right than he knows.

\section{Conclusion}

114 The film shows the bridge and Ryan saved. The Allies retain their foothold on Europe, and Mrs. Ryan retains her J ames. Serving public and private goods proves worth the effort and complementary to boot. Thus Saving Private Ryan solves the problem that causes Miller and his unit so much trouble. Its solution is the stuff of Hollywood endings, however, requiring that we cross a bridge to the surreal. Had the P51s taken a little longer to arrive, had Reiben not noticed the German tank aiming at Ryan, or had the Ryan of Iowa been like the Ryan of Minnesota, the film's ending would have left us unsatisfied. If reconciling public and private requires such improbable confluences of events, the film concedes that its solution might not work in real life. In the end, therefore, it leaves us less a solution than a deeper understanding of democracy as a problematic. In helping us understand why democracy must remain an unsolved problem, the film makes us less likely to fall for fixes that cause more problems than they solve.

115 One such solution was at work in Nazi Germany. The Nazis came 
to power in part by promoting the view that parliamentary democracy produces bickering that makes it impossible for a state to fulfill its potential. The solution was to eliminate whatever feeds disunity. Family, firm, church, Bundestag, or other institutions threaten the state with disunity. They can attract ambitious individuals and compete with the notion that service to the state is the highest calling. The Reich was to spearhead a theodicy aiming so high that other associations must find a place within its grand scheme, defining themselves only in its terms. Thus the Nazis, as totalitarians, would eliminate private life. Behind closed doors, even in the privacy of the mind, an individual was always to serve the Reich. Everything would become rational, because everything would be for reasons mandated by the Reich. All competing views would be brought into line, by the most rigorous (and brutal) of methods. From outside, of course, it would look anything but rational.

116 The film's final scene brings us back to the elderly Ryan in the cemetery at Normandy. Hunching over Miller's grave, Ryan has returned to stand trial for his life: proving to Miller, the others there, even himself that he did indeed "earn it." The star witness is Ryan's wife. He has earned salvation mainly by being good in her private eyes, not the public eyes of the state. The film promotes the moral, democratic mission of the United States; and it appreciates the goodness of the public good. But it emphasizes the moral goodness of the family in particular and the private realm in general. The main protection against America taking virtue too far is to have more than one judge for Ryan's question. Saving Private Ryan does not solve the problem that sets it in motion, but at least it learns from the Reich's mistake.

(c) Kenneth De Luca, 2005.

\section{Notes}

1 Socrates was said to walk shoeless. Shoes, as extensions of our feet, bear the brunt of our weight and make our contact with the ground. They can stand for our whole bearing. See Aristophanes' Knights, lines 315-318.

2 Compare this with Rousseau's discussion of Rome and Sparta in the Emile (New York, Basic Books, 1979, pp. 39-41). Rousseau tells of a Spartan woman informed that she lost five sons in a war. She responds, "Base slave, did I ask you that?" Learning 
that Sparta won a victory, the mother then goes to the temple to thank the gods. Rousseau's examples are interesting in part because Rome and Sparta are, at least loosely speaking, republics. Saving Private Ryan suggests that republics need the family, yet as a form of political life, republicanism still threatens the family at times. 